\title{
The afterlives of Yi Gwangsu: Narrating the trauma of colonial collaboration
}

\author{
Michael D. Shin \\ Robinson College, Cambridge, United Kingdom \\ mds71@cam.ac.uk
}

\begin{abstract}
This article seeks to examine the repeated appearance of Yi Gwangsu (1892-1950) in South Korean postcolonial fiction as a sign of collective trauma. Yi was a pioneering novelist who was a nationalist hero to his readers, but later became a collaborator who supported Japan's war effort. This article focuses on depictions of Yi in the works of three postcolonial writers - Choe Inhun, Seonu Hwi, and Bok Geoil - whose works bore witness to how traumatic his collaboration was. Their works displayed many of the defining characteristics of trauma such as delayed experience and transmission to others. They were also marked by narrative rupture as represented by Yi's mutually incompatible identities as both a nationalist and a collaborator. Rather than repeating the traumatic event, these stories employed various strategies to create new narratives that attempted to heal the trauma.
\end{abstract}

Keywords: Collaboration, Modern Korean literature, Yi Gwangsu, Choe Inhun, Seonu Hwi, Bok Geoil, Trauma, Postcolonial literature

One of the distinctive features of postcolonial nationalism in South Korea has been the lack of closure towards colonial collaboration. Unlike many other postcolonial states, little was done to punish collaborators after liberation from Japan in August 1945, enabling them to assume important positions in government and politics (Cumings 1981: 151-69). The collaborator issue weakened the already fragile legitimacy of the military dictatorship that emerged in South Korea, becoming a source of tension between the state and civil society. Even after the fall of the dictatorship in 1987, it has continued to be a highly emotional issue taken up by both civic and student groups (Jang 2017; Yi and Sim 2017). In most other postcolonial states, there has been far greater closure on the issue of collaboration as well as fewer instances of it shaking the body politic. Like other postcolonial countries, official nationalism in South Korea has portrayed collaborators as villains of the nation, for example Yi Wanyong (1858-1926), the prime minister who signed the annexation treaty with Japan. However, there are many cases where collaboration has cast a shadow over efforts to portray the nation as having engaged in a heroic struggle to overcome the oppressive rule of the colonizer. For instance, the proclamation of the Declaration of Independence, written in 1919, has been considered to be a seminal moment in modern Korean nationalism, but its author, Choe Namseon (1890 1957), later became a collaborator. 
One strategy for dealing with the issue has been to erase it. During the Cold War, when South Korea was under a military dictatorship, the topic was virtually taboo, not least because Park Chung Hee, ruler of the country from 1961 to 1979, wanted to minimize his own past as a collaborator (Jeong 2002: 146). The first and virtually only work on the topic during those years was Im Jongguk's (1929-1989) On Pro-Japanese Literature (Chinil munhangnon), published in 1966. Only after the fall of the dictatorship and the end of the Cold War was it possible to undertake sustained scholarly research on the issue (Kim 2016: 162). There is now a large body of scholarship on collaborators, on fiction by collaborator novelists, and on the government commission created in 2005 that investigated "anti-national activities" during the Japanese occupation.

Though scholars were largely silenced on collaboration for many decades during the Cold War, the issue was not completely suppressed from literature. The stories in which collaborators appeared, though small in number, have borne witness to how traumatic the collaborator issue has been for South Korean nationalism. Instead of focusing on a particular author, this article examines fiction that depicted one of the most famous collaborators, the writer $\mathrm{Yi}$ Gwangsu (1892-1950). If Yi Wanyong was the villain of nationalism, then Yi Gwangsu was its tragic figure since he was a prominent nationalist and was centrally involved in the construction of Korean national identity. His collaboration was so shocking a betrayal that it was traumatic. As the literary scholar Gim Hyeon (1977: 11) argues, Yi is like "a wound that becomes more painful the more one touches it". This article focuses on the fiction of three well-known authors, Choe Inhun (1934-2018), Seonu Hwi (1922-86), and Bok Geoil (b. 1946). They are writers of differing backgrounds and ideological positions who have rarely been discussed together in existing scholarship (Gim Jingi 2006). ${ }^{1}$ What their stories have in common is their portrayal of Yi as an embodiment of the collective trauma of Japanese colonialism.

Analysis of this fiction makes use of the insights of trauma studies, a major subfield of cultural studies. It has built on Sigmund Freud's work on trauma as an experience that cannot be immediately assimilated into consciousness and is thus repeatedly experienced by the victim. Cathy Caruth, one of its most influential pioneers, utilized theories of cultural studies to examine trauma as a narrative rupture that produced a disjuncture between when an event happens and when it is experienced. Though the repetitions bear "witness to some forgotten wound" (Caruth 1996: 5), trauma remains beyond conscious knowing and thus resists narrative (Visser 2011: 273-4). Caruth's work introduced new ways of analysing trauma in both literary and non-literary texts and suggested the potential for making connections among texts from different cultural backgrounds. In many ways, it was postcolonial studies that fulfilled this potential through its critique of the Eurocentric focus that characterized the early years of trauma studies. Their research has demonstrated that trauma does not simply resist narrative but that its victims exert their agency and produce new narratives that attempt to help with healing (Visser 2011: 274). Postcolonial scholars have also criticized

1 The article by Gim Jingi brings up Seonu Hwi to set up an analysis that, as its title suggests, focuses on Choe Inhun. 
the view that "traumatic experiences can only be adequately represented through the use of experimental, (post)modernist textual strategies". They have noted that postcolonial authors have often turned to non-Western, "indigenous literary practices" as well as "localized modes of belief, ritual, and understanding" in response to traumatic events (Craps and Buelens 2008: 5). This article examines the narrative strategies fiction has used to depict the trauma of collaboration, and how three postcolonial writers in South Korea created new narratives of Yi Gwangsu that attempted to heal the trauma.

\section{The collaboration of Yi Gwangsu}

Yi Gwangsu was a pioneering writer who had impeccable nationalist credentials in his younger years. His 1917 novel Heartless (Mujeong), one of the first bestsellers in modern literary history, was a milestone in the development of national literature. ${ }^{2} \mathrm{He}$ was also a political activist who wrote a version of the declaration of independence for a student group in Japan in February 1919, shortly before the March First Movement. He spent some time in the Korean Provisional Government in Shanghai, working as the editor-in-chief of its official newspaper. After returning to Joseon (the name of the country at the time) in 1921, he became the most popular novelist of the time, writing a number of bestsellers including a couple of now canonical works. ${ }^{3}$ What distinguished him from other writers was the fact that his readers came to identify not just with his characters but also with the author himself, wanting to know details of his personal life and treating him in many ways like a celebrity (Shin 2018: 213-4). However, after he and other members of his organization, Donguhoe, were arrested and put on trial in 1937, he began to collaborate actively with the Japanese. He wrote both short stories and non-fiction in Japanese that supported the war effort, receiving a number of literary honours. He gave speeches urging students to volunteer for the imperial army, even adopting a Japanese name, Kayama Mitsurō. ${ }^{4}$

After the country was liberated in August 1945, Yi became a target of criticism, with some lamenting his lack of expressions of guilt or contrition (Gim 1988a: 437-41). Although he had engaged in many of the same activities as other collaborators, the reactions to him were more intense since his readers identified with him so strongly. As the literary scholar Gim Yunsik has written, "when he betrayed the nation, the reason that readers were so enraged and hurt was that they themselves had become Yi Gwangsu. They were not criticizing Yi Gwangsu but were criticizing, crying over, and pained at their own selves" (Gim 1992). In December 1948, he published My Confessions (Na ui gobaek), which was both an autobiography and a defence of his collaboration. Though advertisements for the book promised answers to the question "Is Yi Gwangsu a collaborator or a patriot?", it did little to settle the debate. ${ }^{5}$ When he was arrested in

2 Gim Yunsik has highlighted Mujeong's "monumental nature" (Gim 1999, 1: 566).

3 For an indication of the extent of Yi's popularity, see Samcheolli 1936.

4 For an overview of Yi Gwangsu's collaboration, see Treat 2012.

5 See the advertisement at the bottom of the first page of Gyeonghyang sinmun, 7 December 1948. The same advertisement also appeared in the Donga ilbo on 10 December 1948. 
February 1949 under the Anti-Nationalist Activities Law, it was expected that the investigation would provide another opportunity for $\mathrm{Yi}$ to come clean (Gyeonghyang sinmun 1949). However, the authorities dropped his case a few months later without indicting him; there were no further opportunities for resolution as North Korean forces abducted him shortly after the Korean War began and took him to the North where, unconfirmed until decades later, he died in October 1950.

Since his death, Yi Gwangsu has existed in a purgatory that no other collaborator has suffered. He has found no final resting place as either collaborator or nationalist; instead, he has existed, uncomfortably, as both. This doubling of Yi can be seen as a consequence of the unresolved nature of the collaborator issue. On the one hand, like many other collaborators, Yi has been exiled from the sites and ceremonies of nationalism. Though he was a pioneer of modern literature, there is no literary prize named after him, no statue in a public park, and no building bearing his name. His situation stands in stark contrast to that of novelist Natsume Sōseki, whose portrait appeared on the 1,000-yen note for many years in Japan. Certain literary historians, such as Jo Dongil, have minimized his contributions to modern literature. One North Korean literary history published in 1960 did not mention Yi even once in its sections on the late nineteenth century to the year 1945 (Gim 1994: 199). He has not suffered the complete obscurity that some collaborators have; instead, his fame has been supplanted by infamy.

On the other hand, Yi has occasionally been celebrated as a prominent writer and given a status normally reserved for the most respected authors as if he had never collaborated with the Japanese. Perhaps the most notable instance was in the 1960s when his life and work were revived at the time of the dictatorship's anti-communist campaigns and the promotion of rapid industrialization. Newspapers and journals published articles and special issues with positive portrayals of $\mathrm{Yi}$, some depicting him as a tragic figure for having been kidnapped by communist forces during the Korean War. His "complete" works began to be published in 1962, omitting his writings in Japanese; in the same year, a biography appeared (Jeon 2016: 452-5). Yi's novels continued to be popular after his death. Their sales increased so much in the 1960s that they became bestsellers; even the set of his complete works sold well. His books remained popular with a variety of readers from middle school students to adults, through to the 1980s (Gwon 2013: 282-4; Gong 2016: 197). Many of his novels were adapted into feature films, the first ones appearing during his lifetime. ${ }^{6}$

As mentioned above, a unique feature of Yi Gwangsu's literary "afterlife" is the fact that he himself has been fictionalized, appearing as a character in works of literature and popular culture. Fiction, rather than film or television, has made the most direct effort to depict the struggle to come to terms with his collaboration. One common feature of these stories is their depiction of Yi as simultaneously a nationalist writer and a collaborator. Caruth has noted that such

6 Movies based on Yi Gwangsu's novels include The Life of that Woman (Geu yeoja ui ilsaeng, 1957), Yujeong (1966), Rebirth (Jaesaeng, 1969), Soil (Heuk, 1978) and of historical novels such as The Sorrowful History of King Danjong (Danjong aesa, 1956) and King Sejo the Great (Sejo daewang, 1970). 
doubling is common in trauma stories, which usually contain dual narratives that are "both incompatible and absolutely inextricable" (Caruth 1996: 7). Rather than simply repeating the traumatic event, however, the fiction on Yi attempted to reconcile Yi's dual identities. Despite their stylistic differences, another common feature is their narrative strategy of presenting a different duality of Yi. By presenting an alternate $\mathrm{Yi}$ who did not collaborate, they opened up narrative possibilities that could lead to new understandings of his collaboration.

\section{Choe Inhun's A Grey Man (1963-64) and Journey to the West (1966)}

Hailed as "the greatest writer of the postwar era" by the literary scholars Gim Hyeon and Gim Yunsik (Gim and Gim (1973) 1996: 408), Choe Inhun was perhaps the first novelist to problematize the continuing presence of the colonial past in South Korean society (Hughes 2012: 14). It is not surprising that the occupation period figured so prominently in his fiction since he was born in 1934 in Hoeryeong, North Hamgyeong province and his childhood coincided with the height of Japan's war effort. After liberation, he withdrew from Seoul National University to enlist in the South Korean army, debuting as a writer after the war while still in the military. Choe enjoyed immediate literary success and renown in his mid-twenties with the 1960 publication of his novella The Square (Gwangjang), which became "essential reading for opening the minds of college students in the 1970s and 1980s". ${ }^{7}$ This novel established him as one of the foremost writers on the experience of national division, ${ }^{8}$ but another distinguishing feature of his fiction was his examination of the impact of the colonial past on the construction of South Korean nationalism (Hughes 2012: 164).

Yi Gwangsu appeared in the two novels that Choe wrote after The Square, though they were less focused on the colonial period than were some of his later works. ${ }^{9}$ A Grey Man (Hoesaegin) and Journey to the West (Seoyugi) were very different in style, with the former being a realist novel and the latter experimental with elements of fantasy. However, they can be examined together since Choe intended the latter to be a sequel to the former (Donga ilbo 1971; Choe 2010: 24). One obvious connection is that they shared the same protagonist, Dokgo Jun. The protagonist of A Grey Man even mentioned Journey to the West, the Chinese classic after which Choe named his novel (Choe (1977) 2008: 330). There are also some similarities in the way they portrayed the duality of Yi Gwangsu. In both novels, a secondary character professes admiration for $\mathrm{Yi}$,

7 The novel has continued to sell well, reaching its 100th printing in the mid-1990s, despite its being briefly banned in the early 1980s (Gyeonghyang sinmun 1996a and 1996b).

8 As Gim Yunsik and Gim Hyeon noted, Choe's novels were "works that fundamentally sublimated the consciousness of refugees into the level of spiritual history" (Gim and Gim (1973) 1996: 380).

9 Jeon Soyeong has also examined the portrayal of Yi Gwangsu in these two novels by Choe Inhun. Jeon's approach differs from mine by focusing on reading Choe's use of $\mathrm{Yi}$ as a critique of the South Korean government's effort to revive Yi as part of its building of state nationalism (Jeon 2016). 
especially for his 1932-33 novel Soil (Heuk). Another character then tries to articulate an alternative to or an alternative version of Yi. If Yi's brief but repeated appearances in A Grey Man hinted at how traumatic his collaboration was, then Journey to the West provided a more extended examination of its impact on South Korean nationalism.

\section{A Grey Man}

A Grey Man (1963-64) was a realistic novel portraying young college-aged people who came to know each other in Seoul in the late 1950s. It focused on two friends attending the same college who, while both were disaffected, differed in their responses to the political situation of the time - the dictatorship of president Syngman Rhee (Yi Seungman). Gim Hak, a political science major, sought to organize with fellow students and wanted to reform society. Dokgo Jun, a Korean literature major, was more of a thinker and refused to become involved in political activity. Although the two of them discussed Yi Gwangsu's collaboration, trauma was not a major concern of the novel since none of the characters appear to be traumatized. However, its structure exhibited some of the key elements of trauma narratives. Repetition was built into its structure as the first and last chapters opened the same way, with Hak visiting Jun's room with a copy of his club's magazine. The novel also employed a double narrative (Caruth 1996: 3, 7) that kept the two main characters separate. The middle section of the novel alternated chapters that shifted their focus between Jun and Hak; there was virtually no direct interaction between them. This narrative structure captured how trauma can impact a person's life without having a conscious awareness of it.

Initially, the colonial experience appeared to have little relevance to the main characters. As Jun observed, "Immediately after Liberation, 'Japanese Imperialism' served for a time as the focus of hatred, but that all ended with the coming of the Korean War. Even before 25 June 1950, anti-Japanese sentiment had already lost its power as a symbol of nationalist solidarity." 10 However, the novel did note some of the material traces of the colonial past that remained in everyday life, such as Japanese clothing (16; work pants, 24-25) and music (65). The fact that Jun's boarding house in Seoul was a "Japanese-style house" (84), one that still had tatami floors and some Japanese furniture (124), was perhaps the most direct hint of the continuing presence of the colonial past. Though characters did not discuss the colonial period much, it was invoked as a cause of the problems of Korean nationalism. For instance, when Hak visits his hometown, his older brother tells him:

Before we even had time to be skeptical about Chinese imperialism we were caught in the claws of Western imperialism. That time of skepticism, that historical opportunity, coincided with the Japanese occupation. Because we were under the bondage of others in that period, the chance to cultivate nationalism was lost (158).

10 Choe Inhun (1977) 2008: 101. References to this novel will be given in parentheses after the quote or relevant section. Translations from the novel are taken from Choi In-hoon 1988. 
As Jun himself later observed, "because of the Japanese kids [sic] we've been bruised at a time when absorption in making a modern nation is necessary" (343).

A Grey Man captured the duality of Yi Gwangsu through the contrast between the two main characters. Their differing views on his collaboration also represented different positions towards Korean nationalism. Hak viewed $\mathrm{Yi}$ as a possible model for writers of his generation. When he tried to convince Jun to write for his club's magazine, Hak praised Yi as being "far better than Kim Tong-in [Gim Dongin]", noting that Yi's novel Soil "alone qualified him as the greatest Korean writer" (14). One of Yi's canonical works, Soil is an agrarian novel that tells the story of Heo Sung, a young lawyer who gave up his life in Seoul to return to his provincial hometown of Saryeoul and devote himself to the improvement of the farmers' lives. Hak wants Jun to write a similar novel that shows what Heo Sung "would have done had he lived today" (15). Hak is not unaware of Yi's collaboration, later deploring, "How utterly absurd for a man like Lee Kwang-su [sic] to have urged the youth he loved so dearly to fight alongside our enemies" (100-1). Though he did not seem to be a supporter of the current government, Hak was an example of a nationalist who separated his admiration of Yi's literature from condemnation of his collaboration in order to revive him as a model nationalist.

By contrast, Jun represented someone whose rejection of Yi's collaboration led to a rejection of nationalism. He showed disdain for Hak's admiration for Yi: “The guy [Hak] praised Yi Kwang-su. A likely sentiment for a layman" (40). It seems that collaboration was one of the main factors behind Jun's disillusionment with nationalism; as he later recalled, "the time I felt loneliest was when I learned of the conversions of Choi Nam-sŏn and Oh Kyŏng-ung [sic]" (130). ${ }^{11}$ Unlike Gim Hak, he repeatedly noted that he was not a nationalist, declaring, "I dislike patriots. By whatever means, I must steer clear of the path that leads to becoming a patriot" (292). His rejection of Yi Gwangsu led him to contemplate a trans-Asian existence; Jun considered moving to another Asian country such as China, Japan, Vietnam, or Mongolia (40). His inability to find a satisfactory alternative to nationalism was manifested in his thinking about Yi. At one point in the novel, Jun tried to think of an alternate ending to Soil, wondering, "Must we go to the village of Salyŏul, like Yi Kwang-su?" (271), but he concluded that that path was not right for artists. ${ }^{12}$

The final chapter of the novel shows that the two main characters remained unchanged. As in the first chapter, Hak brought Jun the latest copy of his club's magazine. It contains an article written by Hak speculating on what would have happened if the Provisional Government in Shanghai had come to power in South Korea. Taking a rigid nationalist position, Hak argues that "they first of all would have thoroughly purged all pro-Japanese elements" (366); however, his views on Yi Gwangsu were still a separate matter as there is no mention of him. Jun continued to declare that he wanted to "become

11 The person the translator indicates as "Oh Kyŏng-ung" was John Ching Hsiung Wu (also known as John C.H. Wu), a Chinese jurist.

12 Similarly, Jun later notes, "my ruin is more painful than the ruin of Salyŏul village. For Salyoul to meet ruin, does that not mean your own ruin? No." (227). 
anything but a patriot" (371). What Jun observes about their conversations can be applied to the novel's depictions of their relationship and of their views on the colonial past: they keep on "going back to where they began" (370) and "cannot help but run in place" (372). Their disjointed relationship can be seen as a figuration of the "incompatible and absolutely inextricable" narratives of trauma. ${ }^{13}$

\section{Journey to the West}

Journey to the West began as a direct continuation of the last scene from A Grey Man, with Jun leaving the room he had entered at the end of the earlier novel. However, it quickly shifts into a very different type of novel inspired by the Chinese tale from which it took its title. Whereas Xiyouji was a picaresque story of a pilgrimage to India, Choe's novel was a voyage into Jun's mind, exploring his mind in the time it took him to walk down the hall of his boarding house into another room. Although it did not adopt a stream-of-consciousness narrative, Choe himself called the novel a "Journey to the West of consciousness" and an "epic poem of concepts" (Donga ilbo 1967). It blurred the boundaries between Jun's physical and mental worlds so that he can interact directly with elements of his own mind in anthropomorphic form. Interestingly, it was in a novel that used narrative elements from a non-Western text that Choe gave a more direct treatment of the trauma of colonial collaboration.

A distinctive part of the novel was Jun's series of encounters with three reallife historical figures: Nongae (?-1593), a gisaeng who sacrificed herself to kill a Japanese general during the Imjin War (1592-98); Yi Sunsin (1545-98), an admiral famous for his naval victories in the same war; and lastly, Yi Gwangsu. The novel was loosely structured as a long train journey with a military policeman who, Jun later learned, was taking him to his hometown of W (78) ${ }^{14}$ At stops along the way, he met first Nongae and then Yi Sunsin, but of the three, he spent the most time with Yi Gwangsu. In fact, the scene with $\mathrm{Yi}$ amounted to about one-tenth of the novel's total length. ${ }^{15}$ Each encounter provided an opportunity to examine an aspect of South Korean nationalism. Yi's presence appeared to be strange since the other two were unquestionable nationalists who had sacrificed their lives for their country. At the time of the novel's publication, however, the military dictatorship was attempting to resuscitate $\mathrm{Yi}$ as a nationalist, finding him useful in its promotion of anti-communist nationalism and highlighting the fact that North Korean forces had kidnapped him during the Korean War (Jeon 2016: 455). Yi's inclusion was consistent with Choe's interrogation of the ways in which the government mobilized history for its ideological purposes.

The setting for the protagonist's encounter with Yi Gwangsu was a blending of Yi's literary and "real" worlds that problematized the relationship between his

13 The novel directly remarks on the strangeness of their relationship: "the friendship between Hahk and Tokko Chun was like the relationship of a man who clings to a woman who is cool to him" (250).

14 Choe Inhun 2013: 78. References to this novel will be given in parentheses after the quote or relevant section.

15 More precisely, the scene takes up 37 out of a total of 347 pages. 
collaboration and his texts. At about the midpoint of the novel, Jun's train travelled into a scene from Yi's novel Soil, ${ }^{16}$ but instead of meeting a character, he found himself in the presence of the author. What connected the two worlds was trauma. The train stopped suddenly because a young woman had thrown herself onto the tracks (175-6). The woman was Yun Jeongseon, Heo Sung's wife, who decided to commit suicide when Sung found out about her extramarital affair. The text did not lead to an encounter with Yi as a model nationalist; rather, it had Jun confront Yi's collaboration. The way that the trauma within the literary text evoked the trauma of collaboration was an expression of how Yi's collaboration was inseparable from his literature. In fact, the characters used Yi's novel to defend their positions on his collaboration.

The scene consisted of Jun's observation of long monologues by a Japanese military policeman and then by Yi Gwangsu, which presented two different versions of Yi. Going beyond the depiction of Yi in A Grey Man, both versions were attempts to reconcile his relationship to South Korean nationalism. To the military policeman, Yi's collaboration was consistent with his nationalism. He first expressed admiration for Yi's novel Soil (176), like Gim Hak in $A$ Grey Man. Heo Sung, whom the policeman saw as "a terrific model of the colonial intellectual" (188), was typical of the peasantry in wanting to raise his status by getting an education and passing the bar examination, as well as by marrying the daughter of a prominent family (179). However, he abandoned both his legal career and his wife to devote himself to his hometown, which he loved more than any woman (186-7). In contrast to the characters in A Grey Man, the policeman used Yi's literature to show how his collaboration was a logical culmination of Yi's life. He argued that Yi's pro-Japanese activities constituted a real-life sequel to Soil (189). He believed that Yi's love for the Joseon people, as expressed in the novel, led him to realize that the best path for them was to become Japanese, praising Yi for being a true patriot who avoided the narrowness of nationalism (190-91). ${ }^{17}$ This account appears to be a sympathetic defence of $\mathrm{Yi}$ as it did not portray his collaboration as a betrayal of the Korean people; it was also close to Yi's defence of himself in $M y$ Confessions, where he claimed that he collaborated for the sake of the Joseon people. The difference from Yi's defence is that the military policeman's account amounted to a denial that his collaboration was traumatic.

By contrast, Yi Gwangsu presented himself as a repentant collaborator who regretted his betrayal of the nation. Asking the military policeman to leave them alone for a moment, Yi told Dokgo Jun not to believe anything that the policeman said (196). He now found every aspect of his collaboration to be indefensible, undertaking a self-criticism that the real Yi never did. He admitted it was wrong to have seen Japan as a civilizing and modernizing force and expected it to treat Joseon as an equal, and later grant it self-rule (197, 199, 201). Although he initially stated that he was deceived by Japan, he

16 A train was an appropriate way to introduce Yi Gwangsu; as the novelist Gim Dongin observed, coincidental meetings on trains or in train stations were a common feature of Yi's novels (Gim 1988b: 55).

17 This account of Yi's collaboration somewhat anticipated recent work on him by scholars such as Jo Gwanja, who has called him a "pro-Japanese nationalist" (Jo 2006). 
acknowledged that he acted out of weakness and despair $(198,200)$. It was also wrong for him to have underestimated the nation and thought it possible for the two countries to become one (202). Instead of helping the Joseon people, his efforts in support of Japan acted as an "opiate to the masses" (203). Rebutting the policeman's reading of Soil, Yi told Jun that he should have written a sequel to the novel in which Heo Sung went into exile to Shanghai (202) to join the independence movement. He believed that he should have done the same thing and gone into exile around the time of the March First Movement. ${ }^{18} \mathrm{He}$ now felt that it was impossible to remain a nationalist while the country was under Japanese rule. Though he thought that his reputation would have been preserved if he had been silent, it was wrong to have stayed in the country (202-03). This portrayal of Yi can be seen as an effort to reconcile $\mathrm{Yi}$ with the Korean nation. As the novelist Gim Dongin, a close colleague of Yi's noted in 1948, an "unconditional apology" for his collaboration was necessary so that "our nation and our Yi Gwangsu could once again welcome each other" (Gim 1988a: 438). The portrayal of an apologetic Yi appeared to present a way to achieve closure about his collaboration and restore the sanctity of nationalism.

The encounter with Yi Gwangsu ended on a somewhat ambiguous note. After the fictional Yi stopped talking, the policeman asked Jun if he would stay to take care of Yi, enticing him with the prospect of learning how to write fiction from him (209-10). Faced with choosing between two incompatible versions of Yi, Jun refused the policeman's request and got on the train to continue his journey, as even Yi told him to leave and learn how to write on his own. It seems that Jun chose to accept Yi's views on his collaboration; however, since the novel quickly moved to another scene and did not have Jun explain his choice, it is unclear whether there was any closure or whether the efforts to overcome the duality of Yi simply produced another duality that repeated the trauma.

\section{Seonu Hwi's “Implication” (1971)}

Seonu Hwi occupied a different place in the literary world to Choe Inhun. Whereas Choe was famous for his full-length novels and maintained a critical distance towards politics, Seonu was an establishment figure, mainly known for his short stories. The two novelists, however, had similar backgrounds. Seonu was also from the northern part of the peninsula, fought in the Korean War, and debuted as a novelist while still serving in the army. He was born in Jeongju in North Pyeongan province, the same hometown as Yi Gwangsu. After liberation, he got a job as a reporter at the Joseon ilbo, whose owner was also from Jeongju. Soon after, he joined the army as an officer, serving through the years of the Korean War. After he left the army in the late 1950s, he rejoined the Joseon ilbo in 1961, working in a number of editorial positions including editor-in-chief and becoming part of the conservative establishment. As he was known for his portrayal of people of action in his stories, "Implication" (Muksi) represented a shift in his fiction with its more passive

18 The real Yi Gwangsu did go to Shanghai in 1919; however, he returned to Joseon in 1921. 
and contemplative protagonists (Gim 1971). The short story mainly consisted of characters sharing stories that transferred a trauma from one to another, also showing its progress from its origins to collective experience.

The beginning of "Implication" immediately established that the narrator, whose name was never given, was traumatized by Yi Gwangsu's collaboration. A young student during the colonial period, he decided to commit an act of terror against $\mathrm{Yi}^{19} \mathrm{He}$ had been especially proud of $\mathrm{Yi}$ since they were from the same hometown; Yi's literature had a significant influence on him, as was true for the characters in Choe Inhun's novels. Yi's collaboration made him so enraged that he could barely contain himself (183). When he told a trusted teacher about his plans, the teacher tried to dissuade him by explaining Yi's reasoning. Though the teacher noted that Yi felt that he was acting as a "sacrificial lamb" to save the nation, ${ }^{20}$ the narrator saw Yi as no different from Yi Wanyong (185). For the narrator, whose reaction was portrayed as being typical of the vast majority of people, collaboration was a simple matter; Yi Gwangsu was a villain who needed to be punished violently for his betrayal of the nation.

Yi's double in the story was a friend with no real-life counterpart who was not so much a foil to $\mathrm{Yi}$ as an alternative version of him. ${ }^{21}$ Failing to get through to the narrator, the teacher then told him the story of another writer named Seo Nang, who was a close friend of $\mathrm{Yi}$. They were equally talented at literature, with the difference that Seo was a poet. Being the same age, the two were so close that Yi used Seo's wife as the model for the character of Yeongchae in his novel Heartless (189). They were virtually identical except for their politics. During the March First Movement, Seo dissuaded friends at school from going to Seoul to participate in demonstrations as he believed that it would be impossible to achieve independence at that point in time. Though Seo initially appeared to be more of a collaborator than $\mathrm{Yi}$, he became a version of $\mathrm{Yi}$ who chose to remain silent rather than collaborate.

The plot of Seonu's story was structured as a double narrative, giving two different versions of Seo Nang's story. The first was the commonly known myth about him; the second was the true, behind-the-scenes account. The effect of this double narrative was to create reversals that undermined the narrator's views on collaboration. Commentary on "Implication" published around the time of its publication generally saw it as an attempt to draw a comparison between the two writers that was unflattering to Yi. For example, a critics' roundtable published in the Gyeonghyang sinmun, which included Baek Cheol (1908-1985) and Im Heonyeong, noted that Seo's behaviour was "several tens of times better than Yi Gwangsu's betrayal" (Gyeonghyang sinmun 1971). Such comments missed the point of the short story; for the narrator, Seo Nang's story had the opposite effect, leading him to understand rather than reject Yi.

19 Seonu Hwi, "Muksi" (Implication), Seonu Hwi munhak seonjip 2 (Seoul: Joseon ilbosa, 1987), 183. Page numbers for references will be given in parentheses after the quote or relevant section.

20 The teacher made the same arguments that Yi himself had done in his own defence of his actions, My Confessions (Na ui gobaek) (Yi 1962: 271, 277).

21 Gim Chisu sees Seo and Yi as illustrating two different patterns of behaviour when intellectuals are faced with coercion. See Gim Chisu 1971. 
The crux of Seo Nang's story was how to interpret his unexpected behaviour at a public event in the late 1930s. Both Seo and Yi were speakers at a lecture on literature; shortly after beginning his talk, Seo abruptly stopped speaking, apparently unable to continue. This event was a turning point for both writers. For Yi, it marked the beginning of his collaboration with the colonial authorities. In the case of Seo, people wondered whether his muteness, which continued after the event, was real or fake. The first version of the story portrayed Seo as an apolitical writer who carried out a subtle and clever act of political resistance. Young students thought that Seo was faking his muteness in order to avoid collaborating (189-91). When there was a rumour that he went to Mount Geumgang to seek treatment, people thought he was going into political seclusion, comparing him to the brothers Boyi and Shuqi of Chinese legend (191). Seo's apparently feigned muteness gave people hope at a time when the narrator was feeling powerless $(192,195)$; earlier in the story, the narrator had told his teacher that Yi should have stayed quiet (186). Though Seo's story did not initially change the narrator's mind about Yi's collaboration, the teacher was successful in dissuading him from attacking Yi. However, by the time of the country's liberation, the narrator's feelings towards Yi began to change. He now had "sympathy" for Yi, feeling disgusted with people who called for punishment of others without reflecting on their own behaviour (193).

Liberation did not end the narrator's trauma but seemed to shift it to Seo Nang. If Yi's collaboration was the original event, then Seo embodied its delayed experience. It was not until 20 years after liberation, which would have been around the time that South Korea and Japan normalized diplomatic relations in 1965, that the narrator found out the truth about Seo Nang's silence. By the end of the colonial period, the narrator forgot about Seo as did his colleagues at work (193). Since Seo remained silent after liberation, people came to think that his muteness was real and not a deliberate act of political protest. The narrator now felt disillusioned with Seo, as he had with Yi Gwangsu (195). Hoping to resist falling into disillusionment, the narrator tried but failed to find information on Seo's whereabouts. Decades later, the narrator had a chance encounter with Seo's son, a medical doctor, at an inn in Chungcheong province. Proclaiming that evening to be "the best experience" of his life (196), he finally learned the true story of Seo's muteness.

The second version of Seo's story showed that his muteness was not a political act of resistance but a symptom of trauma. It turned out that he had indeed pretended to be mute at first, but there had been no political motivation. At the lecture, thinking that the audience was mocking him, he suddenly made a decision not to speak. Though he originally planned to tell his wife and son the truth, he changed his mind a few days later. He was not trying to protect his family from the police; rather, his decision was rooted in an "aesthetic sadism" (200) as he found their sorrow to be moving. The country's liberation from Japan did not end Seo's muteness but was simultaneous with the internalization of trauma. On the day of liberation, Seo tried to speak to his wife and son but found himself unable to do so. Exhibiting further signs of trauma, he "lost the ability to think for a while. His heart was filled with emptiness" (202). What was unusual was the fact that he continued to pretend to be mute though he regained the ability to speak several months later. When his wife was on her 
deathbed, he wanted to speak with her one last time but, in the end, just gave her a last hand gesture (204). He did not reveal that he could speak until he was on his own deathbed during the Korean War (199). To the end, the trauma governed his family life.

Rather than resolving his trauma, the story ended with its transmission to others, another common characteristic of trauma (Visser 2011: 275). Over the course of their conversation, the narrator noticed that Seo's trauma was transferred to his son. If the story depicted the overwhelming impact of trauma on personal life through Seo Nang, then it portrayed the burden of historical trauma through the son. Whereas Seo Nang's existence became reduced to his personal life, his son virtually had none. He had no family; the story made a point of showing that he had no relations with women (208). He appeared to have no home, wandering through the countryside and treating people in villages that had no doctor (197). As the narrator parted from Seo's son, he imagined that the son's "two shoulders are being weighed down by a heavy and invisible burden" (209). The story reversed the usual narrative of collaboration; instead of the traitor being punished or condemned, those who did not collaborate bore its burden as if someone were taking revenge on them (202). The "implication" was that Seo's family bore this burden because they had benefitted from Yi Gwangsu's collaboration. The account of the public lecture from the 1930s noted Yi's "unusual" behaviour (190); that is, how he got up and made pro-Japanese comments when he saw what happened to Seo Nang. The suggestion was that his collaboration was a sacrifice for the sake of others, just as $\mathrm{Yi}$ claimed in My Confessions.

Rather than disrupting relationships between the characters, the transmission of trauma created unspoken bonds between them, suggesting the possibility of trauma being the basis of a community. Although learning the true story brought no resolution for the narrator, it did establish a connection between him and the son. By the next morning, the narrator felt that there was no need for words between them even as they both knew that they would not meet again (209). At the end of the story, he further observed that "it seemed to be a burden that someone must bear whether it is something that he chose to bear, something that his father Seo Nang transferred to him, or something that those living in this world such as me have been forced to take charge of" (209). "Implication" depicted collaboration as a collective burden that must be shared by all the people who survived the trauma of Japanese occupation.

\section{Bok Geoil's Searching for the Epitaph (1987)}

Bok Geoil was part of a generation whose path to literary success differed from that of earlier writers. A graduate of Seoul National University, he worked for a number of years at a company before quitting in the early 1980s to devote himself to writing. He skipped the usual path of debuting with a short story and then trying to win a writing contest before writing a novel (Gyeonghyang sinmun 1987b). His debut was the full-length novel, Searching for the Epitaph: Keijo, Shōwa 62 (Bimyeong eul chajaseo: Gyeongseong, Shouwa 62nyeon). It received much critical acclaim and was an immediate success with its first printing selling out in ten days (Gyeonghyang sinmun 1987a). Soon after it was published, one literary critic hailed it as one of the two most notable novels of its time, along 
with Jo Jeongnae's roman fleuve The Taebaek Mountains (Taebaek sanmaek) (Han [1987] 1993: 2: 329). ${ }^{22}$

Bok was one of a group of writers debuting in the late 1980s and early 1990s whose experiments with narrative led them to be labelled "postmodern" (Gyeonghyang sinmun 1992). The literary critic Gwon Taegyeong saw Searching for the Epitaph not only as "the first postmodern novel produced in the [South Korean] literary world" 23 but also as the only successful attempt at one in those years (Gyeonghyang sinmun 1992). ${ }^{24}$ Though it would now be debatable whether Bok is a postmodern writer, it is undeniable that his use of alternate history was innovative and caused a sensation. The novel portrayed a world in which An Junggeun (1879-1910) did not assassinate Itō Hirobumi in Harbin in 1909 but just injured him. As a result, Japan allied with the United States rather than the Axis powers in the Second World War, enabling its empire to exist up to the present time of the novel, the year Shōwa 62 or 1987. Though alternate histories, like their close counterpart counterfactual history, have been valued for their ability to provide a fresh perspective on "actual" history (Hellekson 2001: 1), the emphasis on their use of non-factual situations has obscured the fact that this genre can be used to depict aspects of reality that are not readily apparent in daily life. As it depicted a still existing Japanese empire, the novel can be seen as a literalization of the lack of closure toward Japanese imperialism.

The plot of the novel reversed the typical story of a collaborator, focusing on the rediscovery of Korean identity by an assimilated Korean (Gwon 2002: 35). The main character was an ethnic Korean named Kinoshida Hideyo, a middle-aged salaryman who wrote poetry in his spare time and was culturally completely Japanese. The beginning of the novel emphasized that he was thirtynine years old, meaning that he was born in 1948, the same year that South Korea was officially founded. His birth year suggests that Hideyo's story can be seen as an allegory for the country as a whole. ${ }^{25}$ By 1987 Japan's assimilation policy towards Korea was so successful that Koreans forgot their language and history and lost virtually all sense of a unique national identity. The policy worked by denying Koreans any access to knowledge about Korea. However, the greatest obstacle to recovering a Korean national identity proved to be $\mathrm{Yi}$ Gwangsu. Though Yi was not mentioned until the second half of the novel, his presence loomed over the whole story. ${ }^{26}$ In fact, the epitaph mentioned in

22 Jo Jeongnae's novel was serialized from 1983 to 1989.

23 Gwon Taegyeong quoted in Gim Hyeonsuk 1994: 385.

$24 \mathrm{He}$ is now equally known as a conservative commentator with unconventional and provocative views. He has, for instance, called for the designation of English as an official language and the adoption of the American dollar as South Korea's official currency (Bok 2008).

25 Han Gi has observed that Hideyo's age is the same as the number of years of contemporary history (hyeondaesa) (Han 1998: 339).

26 Bok Geoil, Bimyeong eul chajaseo: Gyeongseong, Shouwa 62nyeon (Searching for the Epitaph: Keijō, Shōwa 62), third edition (Seoul: Munhak gwa jiseongsa, 1998 (1987). The principal sections on Yi Gwangsu are chapters 92-94. All references from the novel have been taken from this edition with page numbers given in parentheses after the quote or relevant section. 
the title was the one on Yi's tombstone, though this fact was not revealed until the midpoint of the novel. In the alternate reality of the novel, what remained constant was that Yi was a figure of trauma. The novel can be seen as an attempt to overcome the trauma of Yi Gwangsu by its use of reverse narrative which seemed to undo the work of collaboration.

The protagonist's search for a national identity began with his discovery of a few surviving fragments of Korean culture. Since the public expression of Korean identity was virtually illegal, the process began in his private life. A chance look at his family's genealogy at his uncle's house stirred Hideyo's curiosity about Joseon (1: 158). His uncle told him that their family belonged to a royal clan whose progenitor was Bak Hyeokgeose, the legendary founder of the kingdom of Silla (1: 160). Additional chance encounters led to other potentially useful fragments. For instance, he found a collection of pre-modern Korean poetry in a used bookstore; an old monk gave him a copy of Han Yongun's poetry (2: 69). As these fragments no longer cohered into a national identity, he began to search for additional knowledge that would fill in the gaps. On a business trip to Tokyo, he took a side trip to Kyōto to visit the library of Kyōto Imperial University, where the Korean books from Keijō Imperial University ("Keijō" being the Japanese name for Seoul) had been relocated (2: 101-03). He made copies of Bak Eunsik's 1915 book The Painful History of Joseon (Joseon tongsa) and other books to bring home.

The repressive force of the colonial past was embodied by the colonial authorities who targeted Hideyo for his interest in Korea. When a customs official discovered the materials that he had collected, he was arrested on suspicion of being a "thought criminal" (sasangbeom) (2: 168). The authorities first used confrontational methods to try to undermine Hideyo's interest in Korea. After a series of interrogations, he had a session with Hakuyama Masaomi, an ethnic Korean who worked for the League for Patriotic Thought (Sasang Boguk Yeonmaeng) (2: 201). ${ }^{27}$ Unlike the other interrogators, Hakuyama tried to put Hideyo at ease, telling him that he likely would not have to go on trial and just undergo "re-education" (2: 217). The objective of the re-education was to have him repeat the basic education necessary to become a devoted citizen of Japan. On the very first day, Hakuyama gave him three books, including Hwangguk sagwan (The imperial country's view of history) and one on the Japanese language, telling him to read a chapter from each and write a report by the next day (2: 203). Hakuyama began a conversation with him about the importance of conversion (jeonhyang), expressing his confidence that Hideyo would eventually agree with him.

The novel portrayed Yi Gwangsu as a much greater threat to the stability of Korean national identity than the more directly repressive methods of the colonial authorities. One day, Hakuyama abruptly asked, "Did you know that Kayama Mitsurō [Yi's Japanese name] fought for Joseon's independence

27 The real Siguk daeeung jeon-Seon sasang poguk yeonmaeng was established in July 1938. Its membership consisted of Koreans collaborating with the Japanese, and the group's purpose was to engage in ideological warfare and to persuade non-collaborators to undergo conversion (jeonhyang). It was disbanded in December 1940 (Chin-Ilpa inmyeong sajeon pyeonchan wiwonhoe 2004: 312). 
when he was young?" (2: 219). In the novel, Kayama was a best-selling ethnic Joseon novelist, but nothing was known of his past. Hakuyama then told Hideyo that though Kayama went to China to fight for Joseon's independence, he came to realize the futility of that struggle. Believing that the only path for survival for Koreans was to become loyal citizens of Japan, he decided to collaborate with the Japanese. Kayama called himself an "unhappy Prometheus" (2:219) since the Joseon people would criticize his decision even though he was doing it for their sake. However, he believed that history would eventually justify his actions. Hakuyama also revealed the truth behind Kayama's novels. He told Hideyo that Kayama's historical novels about the descendants of the Mongol empire were originally written about Joseon history. After his conversion, he rewrote them all to eliminate any connection with Korea (2: 226). ${ }^{28}$ Hakuyama concluded by telling him that the epitaph on Kayama's tomb, located in his hometown of Jeongju, read "Here sleeps Kayama Mitsurō" (2: 230). When Hakuyama fell silent, Hideyo realized that this was the end of his "re-education". In other words, the aim of re-education was to force him to confront the significance of Yi's collaboration.

Learning that $\mathrm{Yi}$ had once been a nationalist and had thus chosen to collaborate with the Japanese was traumatic. Hideyo was "short of breath, his chest constricted by the weight" (2: 220) of what Hakuyama had told him, and he "could feel his thoughts disintegrating like a sand castle in front of Hakuyama's logic" (2: 223).

[He] thought again about what Hakuyama said. With its smooth, flowing logic, Hakuyama's calm voice stirred his gloomy heart like the resonance chamber of an old musical instrument. The Japanese empire, the third most powerful country in the world - in front of this fact, imposing like a sheer cliff, all discussion of Joseon stopped. No matter how hard you hit the cliff, you will only get bruises on your skin. (2: 231)

The story of Yi's collaboration was useful to Hakuyama because it seemed to undermine the very possibility of a Korean national identity.

Another reversal in the novel was to show that hearing Yi's story did not undermine his incipient sense of national identity but instead deepened it. Hakuyama was so confident that re-education worked that as soon as he finished telling Hideyo about Yi, he submitted a report stating that the results were positive $(2: 234)$. When the prosecutor questioned him at their final meeting, however, Hideyo focused on lying without drawing any suspicion and willingly signed the required loyalty statement just to get out of jail (2: 235-6). Rather than rejecting $\mathrm{Yi}$, he tried to achieve closure about him. While still in jail, he tried to compose a verse mourning Kayama but failed to come up with anything satisfactory (2: 232-3). When Kayama's grave suddenly appeared in his mind, he wondered whether Kayama was truly at rest. He felt that he would be able to put the finishing touches to the poem if he stood in front of Kayama's

28 This part of Bok Geoil's story is fictional. Though Yi wrote fiction in Japanese, he did not rewrite his earlier novels. 
grave, deciding to visit it after he got out of jail (2: 233). Ironically, the trauma of Yi's collaboration became part of his connection to his national identity.

Rather than bringing about his conversion, re-education continued Hideyo's reverse transformation into a nationalist, first turning him into a colonial subject marked by ethnic difference. Though re-education was meant to replace a trial and restore his status as a citizen, Hideyo was still "branded a thought criminal". He was worried that "all people would avoid him, thinking that he was a patient or carrier who could infect them" (2: 238). His company asked him to quit his job, not wanting to draw attention by employing someone watched by the authorities. His family life was also affected as he learned that his wife had slept with an officer in the military police in order to facilitate his release. When the police officer later raped his teenage daughter, Hideyo killed him (2: 310). Suffering discrimination and the violence of colonial rule in a much more direct manner than he had previously made Hideyo realize the gap between the ideology of assimilation and the reality of his colonial status further awakened his nationalist sentiments.

Some scholars have interpreted the ending of Bok's novel as the successful rediscovery of a Korean identity. ${ }^{29}$ After the murder, he realized that he could recover his identity only by leaving the country, saying to himself, "Let's go and become a Korean. Kinoshida Hideyo will escape this land and will become Bak Yeongse [his Korean name] in a free land" (2: 313). He resolved to go into exile and join the independence movement in Shanghai, feeling sad that people would assume that he was fleeing because of his crime $(2: 326)$. As he left, he emphasized again the paradoxical situation of Korean identity, saying, "I am an exile searching for a land where I can be myself" (2: 328). Hideyo's transformation showed that it was possible to become a nationalist after having been assimilated into a Japanese identity, opening up the possibility of achieving closure on Yi Gwangsu's collaboration. The ending of the novel, however, was somewhat ambiguous. Hideyo did not visit Yi's grave as he had once resolved to do; in fact, there was no mention of Yi in the last sections of the novel. It was unclear whether the spectre of Yi Gwangsu had at last been put to rest.

\section{Conclusion}

This article has examined the repeated appearance of Yi Gwangsu in works of postcolonial fiction as a symptom of collective trauma. The fact that Yi was the only writer from the colonial period who could credibly be portrayed as a threat to national identity demonstrated how traumatic his collaboration was. These stories were more than repetitions of the original traumatic event; in fact, only Seonu Hwi's short story revisited it. The fiction can be better understood as efforts to create new narratives that resolved Yi's disruptive impact on Korean national identity.

In the fiction that depicted $\mathrm{Yi}$, what often appeared to be departures from realism were depictions of characteristics of trauma. First, the repetitive nature of

29 For instance, Gwon Myeonga notes that Hideyo "becomes reborn as Bak Yeongse" (Gwon 2002: 38). 
trauma was perhaps clearest in Choe's two novels. He embedded repetition into the very structure of the novel A Grey Man; both novels featured some of the same aspects of Yi, particularly Yi's novel Soil. Second, Seonu Hwi's short story "Implication" depicted the belated experience of trauma. Symptoms did not manifest in the character Seo Nang until the day the traumatic event Japanese colonial rule over Korea - ended. The protagonist of the story did not gain an understanding of the trauma until two decades after the end of the Japanese occupation. Third, all of the fiction contained examples of the transmission of trauma. A Grey Man showed that college-aged students in the late 1950s who had been small children at the time of Yi's collaboration were still dealing with its effects. In both Seonu Hwi's story and Bok Geoil's novel, characters who had not experienced the original trauma became traumatized. Though the telling of stories seemed to be sufficient to transmit trauma, Seonu Hwi's story hinted at the political factors behind it.

Fourth, all of the fiction depicted trauma as a narrative rupture. Like other trauma fiction, these novels and short stories employed a variety of narrative techniques to depict the experience of trauma. They show that postcolonial writers made use of both "postmodern" techniques as in Bok Geoil's novel and of non-Western texts as in Choe Inhun's Journey to the West. The fiction contained dual narratives on Yi that were incompatible with each other. A Grey Man, by introducing the two protagonists in the first chapter, created the expectation that the novel would focus on them; instead, it kept their narratives separate until the end. In the scene where Yi appeared, Journey to the West blended real and literary worlds in a way that abruptly interrupted the story. "Implication" presented two different narratives that shifted the story and appeared to leave Yi behind. The turning point of Bok Geoil's novel was when Yi's secret past as a collaborator was revealed.

The three South Korean writers employed different approaches to reconciling collaboration with nationalism and healing the narrative rupture. In Journey to the West, Choe Inhun depicted a penitent $\mathrm{Yi}$, who expressed regret for his collaboration. Seonu Hwi's short story attempted a defence of Yi by showing how those who remained silent benefitted from his collaboration. Bok Geoil's alternate history reversed the usual narrative of collaboration, showing that a Japanized Korean could become a nationalist again. In contrast to Choe and Seonu, Bok did not portray Yi's collaboration as a lasting threat to Korean national identity. The works of these writers that featured Yi bookended the military dictatorships of Park Chung-hee (1917-1979) and Chun Doo-hwan (b. 1931). Choe and Seonu's works were published in the 1960s and early 1970s during the first stage of Park's industrialization when the government attempted to conceal the collaboration of writers such as Yi and to use them for its mobilization efforts. Bok's novel appeared in the final year of military dictatorship as the developmental model established by Park became outdated and lost the support of the people. Though there were only a few fictional works where Yi appeared, the shift in their portrayal of his collaboration suggested that South Korean society was undergoing a transition in its views on the colonial past, moving closer to achieving a longdelayed closure. 


\section{References}

Bok Geoil. (1987) 1998. Bimyeong eul chajaseo: Gyeongseong, Shouwa 62nyeon (Searching for the Epitaph: Keijō, Shōwa 62), third edition. Seoul: Munhak gwa jiseongsa.

Bok Geoil. 2008. "Chulleongdaeneun hwanyul jabeul su ittneun han gaji bangbeop" (A method to get a hold of the fluctuating exchange rate). Joseon ilbo, 17 September.

Caruth, Cathy. 1996. Unclaimed Experience: Trauma, Narrative, and History. Baltimore and London: The Johns Hopkins University Press.

Chin-Ilpa inmyeong sajeon pyeonchan wiwonhoe. 2004. Ilje hyeopnyeok danche sajeon - gungnae jungang pyeon (Dictionary of organizations coooperating with the Japanese empire). Seoul: Minjok munje yeonguso.

Choe Inhun. 2010. Gil e gwanhan myeongsang (Meditations on the path). Vol. 13 of Choe Inhun jeonjip. Seoul: Munhak gwa jiseongsa.

Choe Inhun. (1977) 2008. Hoesaegin (A Grey Man), third edition. Vol. 2 of Choe Inhun jeonjip. Seoul: Munhak gwa jiseongsa.

Choe Inhun. (1977) 2013. Seoyugi (Journey to the West), third edition. Vol. 3 of Choe Inhun jeonjip. Seoul: Munhak gwa jiseongsa.

Choi In-hoon (Choe Inhun). 1988. A Grey Man. Translated by Chun Kyung-ja. Seoul: Si-sa-o-yong-o-sa.

Craps, Stef and Gert Buelens. 2008. "Introduction: Postcolonial trauma novels", Studies in the Novel 40/1-2 (spring/summer), 1-12.

Cumings, Bruce. 1981. The Origins of the Korean War, vol. 1: Liberation and the Emergence of Separate Regimes, 1945-1947. Princeton: Princeton University Press.

Donga ilbo. 1967. "Nae pilsaeng ui jageop yeogi e geolda" (I stake my lifetime's work on this), 21 January.

Donga ilbo. 1971. “Choe Inhun jak Seoyugi” (Choe Inhun's Journey to the West), 25 August.

Gim Chisu. 1971. "Edal ui soseol junggyeondeul hyeonsil anju ui joro gimi” (This month's novels: signs of premature old age's comfort with reality in veteran writers), Donga ilbo, 22 February.

Gim Dongin. 1988a. "Chunwon ui Na" (Me by Yi Gwangsu), in Gim Dongin jeonjip, vol. 16. Seoul: Joseon ilbosa.

Gim Dongin. 1988b. "Chunwon yeongu" (Research on Yi Gwangsu). In Gim Dongin jeonjip, vol 16. Seoul: Joseon ilbosa.

Gim Hyeon. 1977. Yi Gwangsu munhak ui jeonbanjeok geomto (A general examination of Yi Gwangsu's literature), in Yi Gwangsu, edited by Gim Hyeon. Seoul: Munhak gwa jiseongsa.

Gim Hyeonsuk. 1994. “'Bimyeong eul chajaseo: Gyeongseong, Shouwa 62nyeon' ui uimi" (The meaning of Searching for the Epitaph: Keijō, Shōwa 62). Hyeondae soseol yeongu, no. 1, December.

Gim Jingi. 2006. "Jeongchijeok jayu ui han yangsang - Choe Inhun ui 1960nyeondae soseol eul jungsim euro" (An aspect of political liberty - focusing on Choe Inhun's novels from the 1960s), Sangheo hakbo 17, June.

Gim Yeongmin. 1994. "Nam-BukHan eseo ui Yi Gwangsu munhak yeongusa jeongni wa geomto" (An overview and examination of the history of research on Yi Gwangsu's literature in North and South Korea), in Chunwon Yi Gwangsu munhak yeongu, Yeonse daehakgyo gukhak yeonguwon, ed. Seoul: Gukhak jaryowon.

Gim Yunsik. 1992. "Goauisik ui chogeuk gwa jwajeol" (The overcoming and breakdown of orphan consciousness). Munhak sasang no. 232, February. 
Gim Yunsik. 1999. Yi Gwangsu wa geu ui sidae (Yi Gwangsu and his age), Vol. 1, rev. ed. Seoul: Sol.

Gim Yunsik and Gim Hyeon. (1973) 1996. Hanguk munhaksa (The history of Korean literature), rev. ed. Seoul: Mineumsa.

Gong Imsun. 2016. "Yi Gwangsu boggwon gwa munhaksa gisul ui gwalleon yangsang" (The relation between the revival of Yi Gwangsu and the depiction of literary history), Chunwon yeongu hakbo 9, December.

Gwon Bodeurae. 2013. "Jeogaebal ui mello, jeogaebal ui sunggo - Yi Gwangsu, Heuk gwa Sarang ui 1960nyeondae" (Melodrama and the sublime of underdevelopment Yi Gwangsu's Soil and Love in the 1960s), Sangheo hakbo 37, February.

Gwon Myeonga. 2002. "Guksa sidae ui minjok iyagi - Bok Geoil, Bimyeong eul chajaseo" (The story of the nation in the age of national history - Bok Geoil's Searching for the Epitaph), Silcheon munhak, November.

Gyeonghyang sinmun. 1949. "Je i cha Na ui gobaek - Yi Gwangsu ibeoneun jinsil hoecham?" (The second My Confessions - will Yi Gwangsu truly [show] contrition this time?) Gyeonghyang sinmun, 11 February.

Gyeonghyang sinmun. 1971. "Jugeum ui sojae edal ui soseol habpyeong" (The subject of death: roundtable on this month's fiction), 26 February.

Gyeonghyang sinmun. 1987a. "Soseol 'Bimyeong eul chajaseo' chulpan 10il mane maejin" (The novel Searching for the Epitaph sells out in 10 days), April.

Gyeonghyang sinmun. 1987b. "Beseuteuselleu jakga reul chajaseo 'Bimyeong eul chajaseo' ui Bok Geoil ssi” (Searching for a bestselling writer: Bok Geoil, [the author] of Searching for the Epitaph), 19 November.

Gyeonghyang sinmun. 1992. "'Soseol eun haeche doeneunga' nonjaeng gyeokhwa" (The intensification of the debate on "is the novel being deconstructed"), 29 June.

Gyeonghyang sinmun. 1996a. "100swaedolpa soseol 'Gwangjang' 'Nanjang i...' jakga Choe Inhun-Jo Sehui inteobyu" (The novels Gwangjang and The Dwarf... exceeds 100 printings: interview with the writers Choe Inhun and Jo Sehui), 4 June.

Gyeonghyang sinmun. 1996b. "Choe Inhun hyujeon hu je 3 guk seontaek porodeul bogo gusang" (Choe Inhun conceived [of the novel] after seeing prisoners of war choose a third country after the armistice), 4 June.

Han Gi. (1987) 1998. "Singminjijeok sanghwang eseo ui jeongsin ui moheom", in Bok Geoil, Bimyeong eul chajaseo: Gyeongseong, Shouwa 62nyeon, vol. 2. Seoul: Munhak gwa jiseongsa.

Hellekson, Karen. 2001. The Alternate History: Refiguring Historical Time. Kent, OH: The Kent State University Press.

Hughes, Theodore. 2012. Literature and Film in Cold War South Korea: Freedom's Frontier. New York: Columbia University Press.

Jang Sugyeong. 2017. "Bak Jeonghui dongsang daesin hyeonsumak ... 'chinilpa' 'jongbuk balgaengi' chungdol" (Instead of a statue of Park Chung Hee, a banner ... conflicts over "collaborator" and "pro-North reds"), Hangyeore, 13 November.

Jeon Soyeong. 2016. "Jeonyu appropriation wa tujaenghaneun jeonyu ex-appropriation, Choe Inhun ui Chunwon" (Ex-appropriation struggling with appropriation, Choe Inhun's Yi Gwangsu), Hanguk hyeondae munhak yeongu no. 48, April.

Jeong Unhyeon. 2002. "Inmul bipyeong - Bok Geoil bipan" (Critiquing a person - criticism of Bok Geoil), Sahoe bipyeong, no. 33, September.

Kim, Jeong-Chul. 2016. "On forgiveness and reconciliation: Korean 'collaborators' of Japanese colonialism", in Mikyoung Kim (ed.), Routledge Handbook of Memory and Reconciliation in East Asia. London and New York: Routledge. 
Samcheolli. 1936. "Yeongeo ddoneun Esseueo ro beonyeokhaya haeoe e bonaego sipheun uri jakpum" (Works that we want to have translated into English or Esperanto and sent abroad), 8/2, February.

Seonu Hwi. 1987. "Muksi” (Implication). Seonu Hwi munhak seonjip 2. Seoul: Joseon ilbosa.

Shin, Michael D. 2018. Korean National Identity under Japanese Colonial Rule: Yi Gwangsu and the March First Movement. London and New York: Routledge.

Treat, John Whittier. 2012. "Choosing to collaborate: Yi Kwang-su and the moral subject in colonial Korea", Journal of Asian Studies 71/1, February, 81-102.

Visser, Irene. 2011. "Trauma theory and postcolonial literary studies", Journal of Postcolonial Writing 47/3, July, 270-82.

Yi Gwangsu. 1962. Na ui gobaek (My confessions). Yi Gwangsu jeonjip 13. Seoul: Samjungdang.

Yi Jaedeok and Sim Yunji. 2017. "Ihwa yeodae Gim Hwallan dongsang ape 'chilinpa' paetmal" (A "collaborator" sign in front of the statue of Gim Hwallan at Ewha Woman's University), Gyeonghyang sinmun, 13 November. 